\title{
Jesper Tække \& Rasmus Svarre Hansen: Samfundets vilkår. Habermas og Luhmann. København: Unge Pædagoger. 2009.
}

\section{Lars Qvortrup}

\author{
MedieKultur 2010, 49, 171-174
}

\section{Published by SMID | Society of Media researchers In Denmark | www.smid.dk} The online version of this text can be found open access at www.mediekultur.dk

Jeg tager hatten af for eksperimentet - men jeg synes ikke, at resultatet er blevet vellykket.

Det, jeg taler om, er Jesper Tække og Rasmus Svarre Hansens introduktion til Jürgen Habermas og Niklas Luhmann. Deres bog er, som sagt, et eksperiment. Målet er at introducere to af vor tids største tyske samfundstænkere, Jürgen Habermas og Niklas Luhmann, til - som der står i bagsideteksten - "studerende, undervisere og kunstnere på alle niveauer". Midlet er at kombinere en tekstbaseret teoretisk introduktion med billedbaserede fortolkninger og kommentarer. Den traditionelle akademiske præsentation kombineres med andre ord med en kunstnerisk fortolkning.

Hvorfor er resultatet ikke vellykket? Dels fordi kombinationen af tekst og billeder ikke giver nogen merværdi. Dels fordi tekst og billeddelen hver især ikke er tilfredsstillende, måske fordi de gensidigt begrænser hinanden.

Bogens billedside er holdt $i$ en ekspressiv sort-hvid mixed media-form med portrætter af de omtalte teoretikere (nogle gange tegnede, andre gange indklippede fotografier) kombineret med illustrerende eller kommenterende grafiske collager - en slags sort-hvide decoupager. Når teksten omtaler Machiavelli, ser man et svagt tonet billede af en Machiavelli-statue (p. 62), når begrebet autopoiesis, som er hentet fra cellebiologien, introduceres, ser man et grafisk smukt cellesystem. Nogle gange er portrættegningerne vellykkede. Jeg kan fx godt lide Habermas med hvidt hår, store tykke briller, klumpnæse og hareskår (p. 23 og p. 46). Andre gange har de en simpel, tekstforstærkende effekt, der for mig næsten bliver ufrivilligt komisk, jf. fx portrættet af Habermas på p. 3 i hvid streg på sort baggrund. På bil- 
ledet holder Habermas sig for øjnene, hvilket tydeligvis skal illustrere tekstens udsagn om, at Habermas forblindes af sin egen normative tilgang. Nogle gange bruges illustrationerne til at gengive skemaer: Et i øvrigt velkendt skema over forholdet mellem system og livsverden hos Habermas gengives p. 55, men i en sløret version og lagt ind over en portrættegning af Habermas. Konsekvensen er, at skemaet bliver svært at læse og at bruge. Endnu værre er det p. 48, hvor teksten henviser til detaljer i en figur over livsverdensbegrebet hos Habermas, samtidig med at den pågældende figur er så sløret, at den kun vanskeligt kan tydes. Og da figuren gentages nederst på samme side, dækkes den delvist af et stænk sort blæk, et virkemiddel som Rasmus Svarre Hansen tydeligvis godt kan lide. Endelig synes jeg, at det nedsætter bogens brugsværdi, at en del af siderne er trykt med hvide typer på sort, halvglittet baggrund. Jo, det er grafisk set flot, men det gør det umuligt at lave understregninger i eller randnoter til teksten, og det er jo uheldigt for en introduktionstekst.

Alt dette illustrerer, at den grafiske del begrænses af teksten: Den bliver henvisende, forstærkende og af og til kommenterende, men får ikke lov til at folde sig ud på egne præmisser. Jeg kunne fx godt have tænkt mig, at den havde fåt lov til at være mere humoristisk - uforskammet eller blot underfundig: Uforskammet $\mathrm{fx}$ i tegningen af Luhmann med motorsav (p. 134), underfundig og indforstået fx i den udmærkede portrættegning af medforfatteren Jesper Tække (p. 96), dog delvist gemt bag et skema over 7-trinsskalaen, eller af det indkopierede fotografi af Odense-filosoffen Michael Paulsen i et tusch-stormvejr af streger og klatter (p. 99).

Men hvad så med teksten? Mange steder finder man interessante betragtninger over og kommentarer til de to hovedpersoner, Habermas og Luhmann, men det virker, som om Jesper Tække ikke helt har formået at vælge genre. Skal teksten introducere, eller skal den diskutere? Skal den holde sig diskret i baggrunden og give en pædagogisk og letforståelig (hvis det kan lade sig gøre med Habermas og Luhmann) introduktion, eller skal den svinge sig op på samme sværhedsgrad som de to hovedpersoner, måske oven i købet i en diskuterende form? Og hvem er målgruppen? Nogle steder er det tydeligvis studerende ved medievidenskab, andre gange gives der eksempler fra den pædagogiske verden, men de fleste steder leverer teksten alene en almen introduktion.

Tekstens svaghed er, at den både introducerer og diskuterer. Jeg synes ikke, at det er en god idé, at en tekst, der skal introducere Habermas' teorier, starter med at anholde hovedpersonen for normativ blindhed (p. 3), og det virker også malplaceret at kritisere Habermas for moralsk inkonsistens: "Habermas vil det gode og er en sympatisk tænker, når han altså ikke lige spidder andre tænkere i den udstrækning, de ikke passer ind i hans eget tankesystem" (p. 3). Her blandes teorien og personen sammen: Måtte Marx ikke tjene penge, fordi han var kapitalismekritiker? Vælter Heideggers teorikompleks, alene fordi han flirtede (eller hvad han nu gjorde) med nazismen? Anderledes forholder det sig i øvrigt med introduktionen af Luhmann, som Tække tydeligvis har et mere indforstået forhold til.

Teksten burde også være mere introducerende, dvs. undgå det sværhedsniveau, som karakteriserer både Habermas og Luhmann. Lad mig blot nævne to eksempler: Pp. 101-103 
præsenteres og diskuteres det vanskelige begreb "dobbelt kontingens", herunder forholdet mellem Parsons' og Luhmanns definition af begrebet. Men hjælper det begynderlæseren, at forholdet mellem Parsons og Luhmann beskrives sådan her: "Modsat Parsons, hvor værdikonsensus løser den dobbelt kontingens' problem, så skaber dobbelt kontingens ved Luhmann det sociale som tilgængeligt $i$ al mening, som perspektivet vedrørende ensartetheden eller diskrepansen af opfattelsesperspektiver" (p. 101). Meningen er faktisk god nok, men jeg er bange for, at begynderlæseren for længst er stået af. Eller hvad med definitionen af begrebet socialisation hos Luhmann: "Socialisation er, når det psykiske system udvikler differenceskemaer, der muliggør, at det kan relatere sig til omverdenen" (p. 106). Jeg har selv andre steder fornøjet mig over, at Luhmann vender begrebet socialisation på hovedet. Socialisation er ikke resultatet af fremmedtvang, $\mathrm{fx}$ som underlæggelse under udefrakommende normer. Nej, hos Luhmann er socialisation at forstå som selvforandring med henblik på opretholdelse af egenkompleksitet. Herigennem illustrerer dette begreb, hvordan Luhmann i kraft af sin teorikonstruktion - at systemer er operativt lukkede og kun kommer i indbyrdes kontakt igennem strukturel kobling - er i stand til at forholde sig kontraintuitivt til tilsyneladende velkendte begreber. Det skal dog tilføjes, at Jesper Tække også nogle steder forsøger sig med illustrative eksempler, $\mathrm{fx}$ da det vanskelige begreb mening skal præsenteres (pp. 95-99). Her benytter Tække sine egne vanskeligheder med at give karakterer til mundtlig eksamen som eksempel.

Generelt set er det min vurdering, at introduktionen til Luhmann er bedre end introduktionen til Habermas. I Habermas-delen refereres der stort set kun til to værker, nemlig Den borgerlige offentligheds fremvakst og forfald fra 1962 og Den kommunikative handlen fra 1981. Specielt er det ærgerligt, at den omfattende produktion efter 1981 slet ikke omtales. Sammenlignet hermed går Luhmann-introduktionen mere på tværs i det omfattende værk og refererer begreber og begrebssammenhænge snarere end bøger. I forlængelse heraf må man dog undre og ærgre sig over, at bogen ikke er mere ambitiøs: Først introduceres Habermas (pp. 1-61), dernæst Luhmann (pp. 69-133), dvs. hver godt 60 sider. En tværgående læsning finder man alene i afslutningen (pp. 134-137), og der er ikke noget forsøg på en begrebssammenligning (jf. begreber som system, kommunikation, rationalitet) eller en sammenligning af teori-arkitektur.

Endelig undrer det mig, at de temmelig mange citater fra både Habermas og Luhmann ikke er forsynet med værk- eller sidehenvisninger. Det er unægteligt en svaghed i en introduktionsbog: Hvor skal man læse videre, hvis et bestemt - vanskeligt og udfordrende begreb eller en bestemt argumentation har fanget ens interesse? Hvilken begrebsudvikling finder man fxi de to forfatterskaber? Selv har jeg haft stor fornøjelse af at se, hvordan begreberne interpenetration, strukturel kobling og operativ kobling er blevet introduceret af og har udviklet sig hos Luhmann og til og med er blevet diskuteret af Luhmann selv i de udgivelser af Luhmanns forelæsninger, der er kommet de seneste år. Og så ville jeg nok have vægtet Luhmanns analyser af samfundets funktionssystemer højere, ligesom jeg ville have omtalt hans store videnssociologiske produktion. 
Book Review: Samfundets vilkår. Habermas og Luhmann

Bogen anmelder sig selv på bagsiden: Jesper Tække og Rasmus Svarre Hansen har angiveligt sammen skabt en "indsigtsfuld og æstetisk guide", der "klistrer" læseren til bogen og "lirker selv de mest abstrakte tankefigurer ind i ens bevidsthed på en lækker måde." Lad mig sige det lidt mere kuldslået: Man skal være forsigtig med selvanprisninger.

Lars Qvortrup

Dekan, professor

Danmarks Predagogiske Universitetsskole ved Aarhus Universitet

lq@dpu.dk 